\title{
A NEED FOR NEW RELATIONS BETWEEN THE THIRD SECTOR AND THE STATE: AN EXAMINIATION OF THE CASE OF IMMIGRATION SETTLEMENT SERVICES IN CANADA
}

by

Taylor Elizabeth Margaret Morris

Honours Bachelor of Arts, Global Studies

Wilfrid Laurier University, 2018

\author{
A MRP \\ presented to Ryerson University \\ in partial fulfillment of the \\ requirements for the degree of \\ Master of Arts \\ in the program of
}

Public Policy and Administration

Toronto, Ontario, Canada, 2019

(C) Taylor Elizabeth Margaret Morris, 2019 


\section{Author's Declaration Page}

I hereby declare that I am the sole author of this MRP. This is a true copy of the MRP, including any required final revisions.

I authorize Ryerson University to lend this MRP to other institutions or individuals for the purpose of scholarly research.

I further authorize Ryerson University to reproduce this MRP by photocopying or by other

means, in total or in part, at the request of other institutions or individuals for the purpose of scholarly research.

I understand that my MRP may be made electronically available to the public. 
A Need for New Relations Between the Third Sector and the State: An Examination of the Case of Immigration Settlement Services in Canada

Taylor Elizabeth Margaret Morris

Master of Arts, 2019

Public Policy and Administration

Ryerson University

\begin{abstract}
The purpose of this paper is to explore the need to restructure the relations between the Third Sector and the State. The case of Third Sector settlement services in Canada is examined this proposition. This paper takes the approach of a critical literature review to analyze the changing relationship between the Third Sector and the State in Canada from the early 1600's to the contemporary era. This paper will demonstrate that the State has become restructured to follow neoliberal priorities thereby restricting settlement services and negatively impacting the integration of newcomers. The adoption of collaborative governance is proposed as a way to facilitate access to settlement programming that will support the development of partnerships, capacity-building and the sharing of best practices among settlement service providers. This paper is a call for action to Third Sector organizations and the State to begin to reconcile and strengthen their relationship to better serve newcomers to Canada.
\end{abstract}




\section{Acknowledgements}

I would like to thank my supervisor, Professor John Shields. Thank you for offering valuable insights and resources throughout this project, your knowledge on settlement services is profound and helped to support this research. I would also like to thank my second reader, Professor Janet Lum. Your feedback during the final stages of the MRP process was greatly valued and appreciated. Lastly I would like to thank my colleagues of the Public Policy and Administration program for making the past year a memorable experience. 
In dedication to the Refugee Resettlement programs I had the honor of being apart of.

Thank you for allowing me to

Volunteer;

Learn; and,

Grow within your organization. 


\section{Table of Contents}

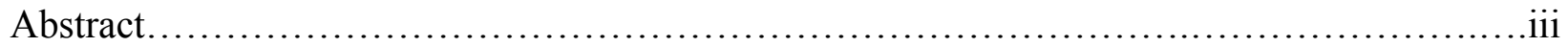

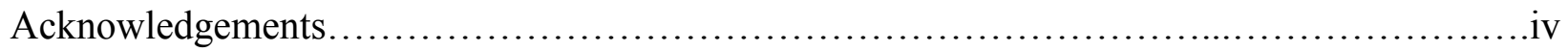

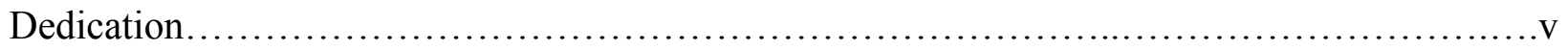

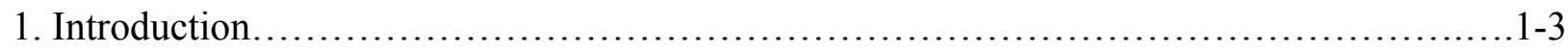

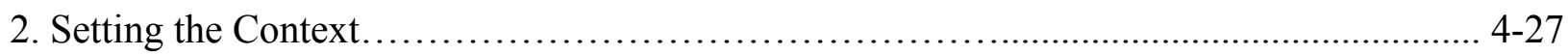

i.) Defining the Third Sector..................................................... $4-7$

ii.) Defining the State........................................................ 711

iii.) Settlement Services in Canada...................................................11-16

iv.) History of Relations ................................................. 16-27

3. Contemporary State - Third Sector Relationship.............................. 28-36

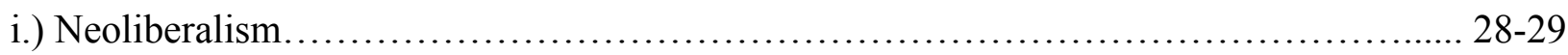

ii.) The Neoliberal State...................................................... 29-32

iii.) Neoliberalism and the Third Sector.......................................... $33-36$

4. Identifying Core Issues in the Provision of Settlement Services......................37-44

5. Restructuring Relations..................................................45-50

6. Recommendations Related to Settlement Services...................................51

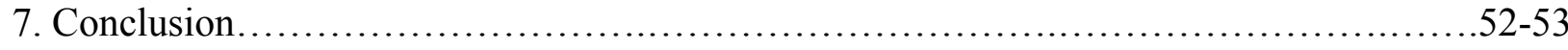

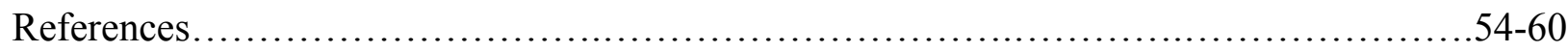




\section{Introduction}

In recent years, the role of the Third Sector has become an increasingly prominent topic. Very few people are aware of the true impact Third Sector organizations can have on society by playing a critical role in developing programs and providing services that meet public needs at a ground level. Unless you have had experience engaging directly with a service provider, community entity, not-for-profit or charity, you are most likely unaware of the role that the Third Sector plays in providing public services and contributing to the public benefit.

Until recently, the disciplines of Public Policy and Public Administration have overlooked the Third Sector in relation to the management of policies and programs. The Third Sector was initially not recognized as having a concrete role in the Canadian political environment and was not even acknowledged as a distinct sector. However, because of the changing relationship between the Third Sector and the State, the Third Sector has gained recognition and prominence. The Third Sector in Canada has been impacted by the development of the nation's political and economic landscape. Because of the increasing disintegration of the boundaries between the Third Sector and governments at national, provincial and local levels, the relationship between the Third Sector and the State has been restructured according to neoliberal priorities and traditional hierarchies of public administration and public policy. In short, neoliberalism has downloaded responsibilities for public administration and policies from the State to the individual and Third Sector.

Today, there continues to be a declining capacity of the Third Sector with respect to citizen engagement and the provision of services. Third Sector organizations in Canada have a 
long history of assisting people and providing services that affect the welfare of citizens, including newcomers. For their part, settlement services work to support newcomers in transitioning to their host community to become fully participating citizens of a new country. Because of the blurring of boundaries between the Third Sector and the State, settlement service agencies are being restructured to focus on time limited funding provisions divorced from community needs.

This Major Research Paper takes the approach of a critical literature review to analyze the changing relationship between the Third Sector and the State. The primary purpose of this MRP is to explore the need to transform the relation between the Third Sector and the State. This MRP uses the example of non-profit provided settlement services to illustrate the relationship between the State and Third Sector. This relationship is a complicated one that can be applied to the public benefit service-providing component of the Third Sector; however, this MRP will focus on the impact on settlement services in Canada. In addition to the importance of building new relations, this MRP will offer a context for considering inclusive and collective approaches to settlement services that can positively help integrate newcomers to Canada.

The first section of this MRP will set the context of the issue by defining the Third Sector as well as the State in a Canadian context. It then explains settlement, emphasizing Canada's role in supporting the provision of settlement services. The MRP will then provide a historical overview of the public administrative relationship between the Third Sector and the State. This section will highlight major events in the history of relations between the State and Third Sector from before the early 1800 s to the modern era, and identify the shifting relations regarding 
settlement services. The following section will describe the contemporary role of the State and Third Sector in Canada, emphasizing the neoliberal undertones that have become dominant characteristics within each institution. Next, the MRP will identify the core issues in the provision of settlement services in Canadian organizations. Lastly, the MRP will focus on how to restructure and rebuild the relations between the Third Sector and the State by focusing on collaboration and engagement. The MRP paper will then conclude with recommendations on how to adopt collaborative mechanisms to achieve a more positive relationship.

The MRP argues that the absence of a clear framework in managing the relations between the Third Sector and the State is restricting the provision of settlement services in Canada. The underlying argument is that a lack of coherence between the Third Sector and the State is negatively affecting the livelihood of people on the ground and calls to Third Sector organizations and the State to begin to reconcile and strengthen their relationship. 


\section{Setting the Context}

\section{i. Defining the Third Sector}

The Third Sector is an umbrella term, encompassing an array of organizations. When defining the Third Sector, it is important to note that the term holds broad connotations as it comes under various names. The Third Sector is often referred to as the voluntary sector, the civil society sector, the social economy, civil society as well as the non-for-profit sector; all of which have partially different defining characteristics (Brandsen \& Pestoff, 2006). Broadly speaking, these often include "charities, cooperatives, interest groups, community organizations, health and social service providers and religious groups" (Laforest, 2011, p.4). These groups often focus on bottom up approaches to governance, and can simply be defined as a nongovernmental organization or institutions that work to serve public needs.

The structural composition of the Third Sector organizations can also vary. Third sector organizations are very diverse, and can be organized in very small community groups as well as very large organizations. The operations of the organizations are often structured through field activity, "such as arts and culture, sports and leisure, health, social services, family and children services, education and religion" (Laforest, 2011, p.5). This concept of field activity works to further emphasize the idea that Third Sector organizations are often grassroots approaches to governance that work from the bottom, often the community, up to the public.

Within the literature on Third Sector organizations, the three essential roles of the public benefit service-providing component of the Third Sector have been defined as representation, 
citizen engagement and service delivery (Reed \& Howe, 1999). These roles are broad due to the imprecise definitions encompassing the Third Sector. However, they do offer insight on how the Third Sector "runs operations": organizations that actively work to represent public concerns and opinions by engaging with the community and are often run by the communities themselves. Third Sector organizations are commonly viewed as a recognized platform, which provides an opportunity for communities to come together to be informed and to discuss policy concerns (Laforest, 2011). Lastly, key to the role the Third Sector plays in society as well as key to the topic of this MRP is its provision of services that aim to meet public needs.

When specifically focusing on Canada, Third Sector organizations have a long history of assisting people and providing services that affect the welfare of citizens. From an economic perspective the third sector "accounts for 6.8 percent of the nation's gross domestic product" (Hall et al., 2005, p.7) and it is growing. Canada has one of the largest third sectors in the world. The 2004 Canadian National Survey of Nonprofit and Voluntary Organizations estimated that the sector encompasses over 180,000 organizations; however, this number excludes organizations that are not formally registered through the provincial, territorial or federal government leaving academics to estimate the total being 870,000 (Laforest, 2011). The organizations are often categorized but not completely defined as service providing agencies and expressive organizations (Hall et al., 2005). Service agencies consist of organizations that focus on health, education and social services (Hall et al., 2005). Examples of such services in Canada include the Sick Kids Foundation, World Vision and the Ontario Non-Profit Housing Association. Expressive organizations provide cultural, religious and recreational activities (Hall 
et al., 2005). Examples of these organizations in Canada can include KEF Toronto, Charity Village and the Canadian Arts Coalition.

Within the Canadian context, the loose definition of Third Sector organizations extends to the differentiation between a charity and a non-profit. In Canada, there is a distinct difference between a charity and a non-profit: all charitable organizations are non-profits, but not all nonprofits are charitable organizations. According to the Canada Revenue Agency (2006), "nonprofit organizations are associations, clubs, or societies that are not charities and are organized and operated exclusively for social welfare, civic improvement, pleasure, recreation, or any other purpose except for profit" (par. 7).

Ultimately, a non-profit does not deposit money to shareholders, is often owned by a community, and is granted a patent by a provincial or federal government. This means that a non-profit in a Canadian context can range from an organization that provides social services to one that provides recreational sporting activities. In addition, according to the Canada Revenue Agency (2006), "registered charities are charitable organizations, public foundations, or private foundations that are created and resident in Canada" (par. 2). These organizations must fall into one of the following categories: the relief of poverty, the advancement of education, the advancement of religion; and, other purposes that benefit the community (Canadian Revenue Agency, 2006). Ultimately, a charity is a special kind of non-profit that receives a charitable status from Revenue Canada. To receive a charitable status, "an organization must provide benefits or services which fit into a set of categories [designed by Revenue Canada] and must not devote more than $20 \%$ of its revenues to activities other than providing those benefits" (Reed \& 
Howe, 1999, p.7). All registered charities in Canada must submit a yearly information return. In addition to this form submitted by the registered charity, all individual donors to that charity can request an income tax receipt (Reed \& Howe, 1999).

Because of the definitional debate, for the purpose of this MRP, the term "the Third Sector" will refer to and encompass all non-profit service providing agencies and expressive organizations as well as all charitable organizations in Canada. In this work, I will give special emphasis to refugee and immigrant settlement service Third Sector organizations. This will allow for an in depth understanding of the sector as a whole in order to recognize the specific challenges in the relationship between the Third Sector and the State. To underline the importance of the "definition" of the Third Sector for this MRP, despite the term's loose definition and composition, it is essential that the identity of the Third Sector within society is not just its service orientation but also the ability of such organizations to act as a vehicle for political participation and citizen engagement (Laforest, 2011).

\section{ii. Defining the State}

Similar to the Third Sector, the State is an umbrella term, which refers to "the institutions of national administration, including the government, the public service, the judiciary, the police, and armed forces" (Stilwell, 2012, p.xx). Since this MRP focuses on Canada, the definition of the State will be from the perspective of Western society. It is important to note that the State does not simply refer to the government, but encompasses much more. Through the years, governments change constantly while states remain. The concept of the government is central to the definition, however. The State refers to a wide variety of institutions. These institutions are 
often comprised of an executive, a bureaucracy, courts, structures of legislative assemblies and administration, regulatory boards, armed forces, police and other institutions that work to manage policies and programs (Paul, n.d.). Broadly speaking, the role of the State and the institutions of national administration that encompass the State is to make a positive legislative environment and policy framework that enables various arms of the State to explore and achieve their potential while maintaining a high standard of operations to protect public interest (Pierson, 2012). Therefore, in contrast to the Third Sector, these institutions focus on top down approaches to governance.

Many academics argue that the idea of the State can only be understood through a historical perspective. When taking a historical perspective, the Western State begins in ancient Greece. "Plato and Aristotle wrote of the polis, or city-state, as an ideal form of association, in which the whole community's religious, cultural, political, and economic needs could be satisfied" (Britannica, 2009, par. 2). This idea of a community sharing culture, religion, history and a common language carried over to the modern idea of the nation seen today. In comparison, the Roman res publica is more common to the modern idea of the state as the Roman concept acted as a legal system, which extended to all citizens in a jurisdiction and secured their rights and responsibilities (Britannica, 2009).

The literature on the composition of the State in society suggests that to understand its complexity, one should try to understand the concept as a whole while emphasizing the tensions among the internal parts. In the case of defining the State, this implies understanding its democratic, capitalist and bureaucratic aspects (Stilwell, 2012). 
To begin, the first step in understanding the State is to analyze its democratic aspects. When understanding the composition of the State the key question is whether the liberal State is democratic. This question has initiated an academic debate that continues in the political arena today. One side of the debate suggests that the State is considered democratic "insofar as it is accountable to the public at large and subject to control through electoral processes" (Stilwell, 2012, p.242). The underlying expectation is that the processes of the State are subjected to the influence of a democratic ruling that works to serve the nation and people's interest at large over specific class or individual interests. The continuous election cycle and "rearrangement of chains of authority may make the administrative dimension of governance more closely subject to democratic and electoral processes" (Mayrl \& Quinn, 2016, p.7). However, in opposition to this position, many academics argue that not all parts of the state are democratic. Some argue, "public servants, judges, and military personnel are typically recruited, promoted, and dismissed according to institutional procedures in which the public has no direct voice" (Stilwell, 2012, p.242). An example of this argument is that although there is an electoral process, "direct elections are focused primarily on the periodic contest for seats in parliamentary and local government assemblies" (Stilwell, 2012, p.242). In addition, there is an argument that in many western societies, economic forces can affect democratic processes. For example, economic inequality can subvert the egalitarian processes underpinning democracy in any electoral process (Pierson, 2012). Examples are evident in the cost of a being an elective candidate, electoral administrative costs, the buying of political influence and the cost of financing a campaign. 
The second step in understanding the State is to examine the extent to which it is a capitalist State. This is asking, to what extent and "how the functioning of political institutions [are] constrained and shaped by the structure of the economic system, and interests of the capital in particular" (Stilwell, 2012, p.243)? In a capitalist society, an economic system is based on the private ownership of the means of production and their operation for profit. There is a growing literature related to the boundaries in structuring social systems, including the boundaries enforced by the State. The constriction of capitalism "creates the appearance of a stark division between state and society, producing the sense that the state is something set apart and distinctive" (Mayrl \& Quinn, 2016, p.4). Under capitalism, the State regulates and enforces property rights, determines the rules underpinning the operations of labour, capital, land, commodities and it controls class relationship (Stilwell, 2012). Critical to this working part is understanding that the State has the power to make its own decisions. For instance, the idea that "the State can also act as an ideological tool to justify political actions or bind individuals to political authority” (Mayrl \& Quinn, 2016, p.4).

The third step in understanding the State is to explore its bureaucratic character. Bureaucratic processes refer to the procedures that are designed to maintain uniformity and controls within large organizations or governments. Bureaucratic processes are commonly applied to ensure that there is a consistency in the processes of public administration (Stilwell, 2012). These processes entail the established methods in large organizations or governments such as the planning, organizing, directing, coordinating, and controlling of government operations. Political actors (that is, both government officials and the nongovernment actors with whom they interact) must reflexively categorize their own actions as either belonging or not 
belonging to the state" (Mayrl \& Quinn, 2016, p.3). However, a critique of extremely strict bureaucratic processes is that "once a large state apparatus is created, its members tend to develop their own interests, which may be different from, even contrary to, those of their political masters in government" (Stilwell, 2012, p.243). This has led to many critics from both right and left to condemn the State as inefficient and ineffective (Pierson, 2012).

To reiterate, the role of the State and the institutions of national administration that encompass the State based on conventional liberal democratic understandings is to make a positive legislative environment and policy framework that maintains a high standard of operations while protecting the public interest.

\section{iii. Settlement Services in Canada}

Settling in a new country is not a simple process and often requires settlement support and services. Immigration as a whole has made a major impact on Canada's social, political and economic climate. It is recognized that from a social and political perspective, "newcomers can play a key role in linking source and host countries as they have knowledge about both countries language, culture, preferences and business environment" (Citizenship Canada, 2019, p.7). In addition, newcomers contribute to the labour market and the economy. For example, "with an ageing population and low fertility rates, immigration plays an important role in ensuring that Canada's population and labour force continue to grow" (Citizenship Canada, 2019, p.2).

Settlement services can be understood as programs or initiatives that are specifically designed to assist newcomers to adjust to their new life in Canada (OCASI \& COSTI, 1999). The 
services provided can vary depending on the newcomer's need and stage in the settlement process. Broadly speaking, there are four general stages of the settlement process:

1. Pre-arrival: when a newcomer is preparing to move to Canada;

2. Initial reception: when the immediate needs of the newcomer are met upon arrival, which may include referrals or temporary housing;

3. Intermediate stage: when newcomers have settled in and are securing longer-term employment, housing and education;

4. Long-term stage: in this stage newcomers are developing a sense of belonging to Canada without giving up their attachment to home. (Praznik \& Shields, 2018, p.5).

A common misconception of the settlement process is that it ends once a newcomer resides in Canada for up to five years, or becomes a Canadian citizen. The settlement process is in fact a lifelong process.

In Canada, newcomers can hold four different immigration statuses that can determine the eligibility of various settlement services. These include: Naturalized Citizens (citizens born outside of Canada and who have passed the citizenship test); Permanent Residents (newcomers who are allowed to stay permanently in Canada); Temporary Residents (newcomers who are allowed to reside in Canada for a pre-determined amount of time); and, Undocumented Migrants (migrants who reside in Canada but do not have legal status or their legal status has expired) (Praznik \& Shields, 2018). According to the 2018 annual report to Parliament on immigration, Canada welcomed more than 286,000 permanent residents in 2017 (IRCC, 2019). This number 
only accounts for one category within Canada, representing individuals and families who continue to come to Canada to start a new life and reside permanently.

Stakeholders and past research have found that the most important factor in the successful integration of immigrants is the level of involvement and understanding of the adopted society (Schmidt, 2007). Therefore, settlement services are a crucial aspect of the integration process a newcomer experiences when immigrating to Canada. Settlement services can include but are not limited to "referrals for housing, healthcare and schools, and accessing employment, language training, and recertification" (OCASI \& COSTI, 1999, p.11). The services can be provided in a multitude of ways including services from Third Sector organizations as well as directly from the government. "Integration is defined as the ability to contribute, free of barriers, to every dimension of Canadian [host society] life, that is, economic, social, cultural and political" (Moreno et al, 2016, p.5). Therefore, the goal of settlement is for every immigrant to have the freedom to contribute to every dimension of Canadian society. Critical to the understanding of settlement services is that they are continuous process between numerous stakeholders. "The settlement process involves not just immigrants and service providers, but policy makers, media, employers, labour organizations, learning institutions, faith communities, neighbors and the broader community" (OCASI \& COSTI, 1999, p.13).

In Canada, immigration settlement policy is viewed as separate from immigration policy. Immigration policy is understood as "the regulation and control of the flow of international migrants into a host country" (Schmidt, 2007, 106). In contrast, immigration settlement policy "refers to efforts by states to regulate and facilitate the ways in which-and the processes through 
which-recent international migrants become integrated into the host society" (Schmidt, 2007, 106). This MRP focuses specifically on immigration settlement policy and the changing settlement process occurring in Canada.

Within the provision of settlement services in Canada, there are different types of service providers. "The four main service providers are civil society organizations, school boards, provincial governments and municipal governments" (Praznik \& Shields, 2018, p.11). It is important to note that civil society organization, otherwise known as Third Sector organizations make up the majority of settlement service providers in Canada. In addition, it is crucial to clarify that federal government does not directly provide settlement services but does fund third parties, including Third Sector organizations to support the delivery of the services to the civil society. Ultimately this means the funding for settlement Third Sector organizations in general are largely dependent upon government revenue.

In Canada, in regards to the State, newcomer settlement in Canada is shaped by all levels of government; municipal, provincial and federal. "Federal and provincial governments have long shared jurisdiction of such matters outside of Quebec, Canada's other provinces and territories have gained an increasing stake in newcomer settlement through a variety of avenues including federal-provincial agreements and Provincial Nominee Programs" (Bushell \& Shields, 2018, p.21). However, because of the funding relationship between the Third Sector and the federal government, the policymaking power in immigration and settlement remains centralized within Canada's federal government. The federal department responsible for Canada's immigration processes is Immigration Refugees and Citizenship Canada (IRCC). The IRCC formally 
describes its activities as "facilitating the arrival of immigrants, providing protection to refugees, offering programming to help newcomers settle in Canada, granting citizenship, issuing travel documents, and promoting multiculturalism" (Neudorf, 2016, p.92). The IRCC's funds settlement services to newcomers who hold the statuses of a permanent resident, protected person, individual inside or outside of Canada who has been approved for permanent residency, convention refugees and live-in caregivers (Praznik \& Shields, 2018).

In comparison, Third Sector organizations play a key role in providing services to newcomers because they have the ability to connect with newcomer communities on the ground. "Literature suggests that non-profit community organizations can offer comprehensive, longterm and culturally and/or linguistically compatible settlement services" (Bushell \& Shields, 2018, p.3). This is because Third Sector organizations work from a community level actively advocating for newcomer needs. Broadly speaking, settlement service providers in Canada can be broken down into five categories:

1. Universal Service Providers: those who provide services to newcomers and those born in Canada;

2. Immigrant Serving Provider Organizations: those who provide direct services to immigrants;

3. Issue Based Organizations: those who provide services based on a specific settlement need (e.g. employment, language, health);

4. Multicultural Non-Governmental Organizations: those who focus on diversity issues;

5. Colleges and Universities; they are considered a type of settlement service provider as 
they accept many international and permanent residents each year and provide various support services on campus (Praznik \& Shields, 2018, p.13-18).

Addressing what statuses of immigrant Third Sector organizations serve in Canada can be tricky, as it largely depends on the source of funding. Different levels of government may be more flexible in eligibility requirements by expanding their eligibility criteria to temporary residents and naturalized citizens (Praznik \& Shields, 2018). However, "community foundations and private donors tend not to make restrictions on who can access the services they fund but rather leave it up to the settlement service provider to decide" (Praznik \& Shields, 2018, p.6). This often allows for undocumented immigrants to receive services in Canada.

\section{iv. History of Relations}

The history of the relationship between the Third Sector and the State in Canada is often overlooked. The history of the public administrative relationship between the stakeholders is considerable and provides insight on the relationship that exists today. Because the policymaking power in immigration and settlement remains largely centralized within Canada's federal government, the historical overview will focus on the federal government while mentioning other institutions of national administration that are relevant to the developing relationship. This section of the MRP will provide an overview of the relationship between the Third Sector and the State in Canada in regards to the provision of social services while highlighting critical events, which affected the state of immigration settlement services and policy. 


\section{Before Confederation-Emergence of the State and Third Sector in Social Services}

In Canada, the emergence of structures that provided social services can be traced to the pre-Confederation period. The earliest idea of providing social services can be traced back to the Indigenous peoples of Canada who inhabited the land for thousands of years prior to European settlement (Hall et al., 2005). The ideology of the Third Sector is rooted in Indigenous traditions as "the concepts of giving and sharing were deeply embedded in Aboriginal culture...[and] although the Aboriginal way of life was disrupted and fundamentally altered by the arrival of Europeans, informal giving and volunteering continue to thrive" (Hall et al., 2005, p.20). In a sense, the Third Sector began with First Nations peoples, was then institutionalized by French and English settlers, and then grew with the arrival of immigrants from around the world.

Pre-Confederation Canada can be divided into three regional groups: Atlantic Canada, Upper Canada, and Lower Canada. The arrival of settlers drove the creation of formal governance structures and services, such as education, welfare and social services (Elson, 2009). Each regional group, also the recognized State at the time but experienced different government structures and policies that shaped the provision of services.

Specifically, Atlantic Canada adopted the Elizabeth Poor Law of 1601, which was influenced not just by England but the American colonies. The Poor Law "obligated municipalities and counties to collect funds for the relief of the indigent and ensure the provision of asylums and other related institutions" (Maurutto, 2005, p.160). The Poor Law was only used provincially in the case of extreme emergencies such as a medical outbreak or natural disaster. The administration of the Poor Law was the first example of the central state in Canada 
developing a policy associated with social services. Despite the development of a central government hand in social services, the Poor Law was controversial in that it created a separation between "deserving citizens" such as those who were sick or suffering a natural disaster, and "undeserving citizens" who were viewed as able bodied people who were nonetheless asking for assistance (Elson, 2009). The idea of undeserving citizens later transformed into the idea of "pulling yourself up by your bootstraps" and largely framed the traditional liberal and neoliberal policy perspectives, which called for minimal state involvement in social policy and supports.

The Constitution Act of 1791 divided Canada into two parts, Upper Canada and Lower Canada. This action transformed the provision of social services in each of these jurisdictions. Lower Canada encompassed the contemporary province of Quebec. Up until the Quebec "Quiet Revolution" of the 1960s, the Catholic Church was a dominant force (Hall et al., 2005). The official model of the Third Sector in Lower Canada up to this point was established under the influence of the Catholic Church, that, supported by the state, only endorsed and financial assisted religious affiliated Third Sector organizations (Hall et al., 2005). In addition to funding religious affiliated social services, the Catholic Church had a hand in most social and economic services in Lower Canada such as medical care and education, "but was also intimately involved in frontier exploration, colony governance, the recruitment of colonists, and the establishment of missions and cities" (Elson, 2009, p.38).

Conversely, the Catholic Church did not strongly influence the government in Upper Canada, which formally rejected the Poor Law. "Upper Canada's rejection of the English Poor Law in 1792 is often interpreted as evidence of the government's early reluctance to assume 
responsibility for social welfare" (Maurutto, 2005, p.160). As a result, accountability for the poor rested primarily with the individual and the family as a predominantly private affair that, in turn, influenced the growth of many Third Sector organizations. Upper Canada funded social services through independent boards that operated directly in municipalities (Hall et al., 2005). "The establishment of charities in Upper Canada took on clear moral and evangelical overtones as, every church, ethnic group, and interest group had its own charitable society or foundation (Elson, 2009, p.40). Upper Canada Third Sector organizations requested support for these organizations from the private sponsors and through independent fundraising initiatives, but also through requests to the government for support of charitable activities.

Critical to the understanding of the three colonies is that although they experienced different state structures, each area experienced institutional shifts of responsibility for the poor. In response to failures of the Poor Law in Atlantic Canada, the late $18^{\text {th }}$ to $19^{\text {th }}$ century experienced a growing influx of Third Sector organizations to provide services to all of those in need and not just to "deserving" citizens (Elson, 2009). Additionally, in the late $18^{\text {th }}$ and $19^{\text {th }}$ centuries, citizens began to question the dominance that the Catholic Church held in Lower Canada as well as the power it had over social services. Moreover, from the beginning, civil society in Upper Canada was pressured to be accountable for the provision of social services.

\section{0's -Early 1900's - Political and Social Reformation}

In the 1830's the growing needs of the civil society began to attract government attention. A series of widespread medical outbreaks countered the image of the poor as an undeserving 
class (Maurutto, 2005), leading reformers to push the government to redefine the responsibility of poverty to be more than a private matter and to take public action.

July 1, 1867 marked Confederation. "Confederation refers to the process of federal union in which the British North American colonies of Nova Scotia, New Brunswick and the Province of Canada joined together to form the Dominion of Canada — a new country" (Waite, 2013, par. 1). The Constitution Act of 1867 awarded the provinces control over health, welfare, and education, including hospitals, charities and asylums, as the federal government was reluctant to provide more than residual support for social services (Elson, 2012). This was because at the time, the federal government considered these issues minor, and primarily, local concerns.

Moving forward, "from the late 18th century until the early 20th century Canadian history was dominated by three major trends: immigration, westward expansion, and the challenge of forging a new nation in a vast and sparsely populated land" (Maurutto, 2005, p.20). The late 1800 's to early 1900 's experienced major political and social reforms, which transformed the relationship between the Third Sector and the State. This time-period has been characterized as the golden age of philanthropy (Elson, 2009). Until the late 1800's citizens and religious organizations acted as the primary drivers of Third Sector organizations. "Governments provided funding when they were obligated under the Poor Law [or the spirit of the poor law], but otherwise saw social services as a means to control social unrest rather than a way to increase equitable access to services and opportunities" (Elson, 2009, p.41). One of the first major government moves that affected the Third Sector was the 1891 Pemsel case, which provided a definition and classification for the term charity: 
"Charity, in its legal sense, comprises four principal divisions: trusts for the relief of poverty; trusts for the advancement of education; trusts for the advancement of religion; trusts for the purposes beneficial to the community not falling under any of the preceding heads" (Elson, 2009, p.43).

Due to the reluctance of the government to take on more responsibility in social services, Third Sector organizations expanded rapidly. This development of the Third Sector "resulted in the creation of local centralized governing bodies, which [were] designed to streamline charity work and impose a degree of administrative efficiency and accountability" (Maurutto, 2005, p.161). Third Sector organizations worked to identify needs and to meet those needs to the best of their ability. Governments however did not engage in social services unless there was a political or economic necessity. For example, one of the first times the government of Canada engaged with social services was to provide financial aid programs for WWI veterans (Lautenschlager, 1992). The second major change was the 1917 War Charities Act and Income War Tax Act. The War Charities act was implemented as a way to register and regulate charities. The Income War Tax Act allowed for tax reductions from donations to war charities such as the Canadian Red Cross (Watson, 1985). When WWI came to an end both acts were repealed, although "a limited tax reduction (ten percent) for donations to hospitals, asylums, and related charities continued" (Elson, 2009, p.43). This moment is critical to understanding the relationship between the Third Sector and the State as the regulation of the Income Tax Act dominated the policy discourse on voluntary sector-government relations (Elson, 2012), as well, marking the moment when Canada began to distinguish between charities and non-profits. 
In regards to immigration settlement and policy, 1869 marked the adoption of Canada's first Immigration Act. The Act contained no specific provisions to refugees and "primarily focused on ensuring the safety of immigrants during their passage to Canada and protecting them from exploitation upon their arrival” (Canadian Museum of Immigration, n.d.). The Act included an outline of safety procedures for ship captains to follow-- such as restrictions on the number of passengers onboard to prevent overcrowding to ensure immigrants' safety. At this time, there were no distinct settlement policies in place. In addition, following the First World War, "hundreds of thousands were displaced in Europe. Canada opposed the admission of refugees on the grounds that once admitted stateless refugees could not be deported" (Canadian Council for refugees, n.d.)

\section{0's - Growth of the Third Sector}

World War I began on July 28, 1914 and lasted until November 11, 1918. The great Depression of the 1930s followed the end of the war and a period of economic growth during the 1920s and imposed hardship on the lives of many Canadians. Third Sector organizations struggled to raise funds, which caused many Canadians to look to municipalities for support (Maurutto, 2005). However, municipalities did not have the resources or funding to address the needs of so many Canadians. Once again, organizations turned to the federal and provincial governments. The Great Depression highlighted that the State needed to play a larger role in providing social services to society. "The federal government responded [and] subsequently increased its funding for employment relief measures" (Elson, 2009, p.44). In addition, the federal government made an amendment to the Tax Act that allowed donations to any church, 
university, college or school to be included as a tax deduction (Watson, 1985). Shortly thereafter, the government of Canada amended the Act again to include any charitable organization. During the Great Depression, Third Sector organizations continued to provide services within their ability such as shelters, food kitchens and clothing donations.

World War II ironically stimulated the economy to end the Great Depression. After WWII, Canada again saw a growth in Third Sector organizations, as all levels of government increased spending on health, education and social services (Hall et al., 2005). Between the mid1940s to the 1980's new social policies were adopted that impacted health, education and an array of social services (Watson, 1985). With new social policies came an adoption of new funding structures. Third Sector organizations began to adopt new mechanisms: many pursued mixed funding structures based on government support and donations while others depended entirely on government funding (Maurutto, 2005). These mixed funding structures have continued into what is now the modern fiscal relationship between the Third Sector and the State.

In regards to immigration settlement and policy, immigration slowed between the two world wars but began to pick up in the late 1940s. The first articulation of a Canadian refugee policy was seen in Prime Minister William Lyon Mackenzie King's statement to the House of Commons on immigration policy on May 1, 1947. "In it he stated, the resettlement of refugees and displaced persons constitutes a special problem...Canada is not obliged...we have, nevertheless, a moral obligation to assist in meeting the problem, and this obligation we are prepared to recognize" (Vineberg, 2018, p.1). In 1944, the Department of Mines and Resources had responsibility for immigration. A separated ministry dealing solely with immigration issues, 
the Department of Citizenship and Immigration, was established in 1950 (currently known as Immigration Refugees and Citizenship Canada (IRCC). “Canada's current approach to immigration policy, begun in 1962, [and] signalled a new willingness on the country's part to welcome international migrants from all over the world" (Schmidt, 2007, p.107). In 1971 Canada became the first country in the world to adopt multiculturalism as an official policy, which contributed to the creation of a new Third Sector initiative, government supported settlement and multicultural services offered through non-profit providers. After the Second World War Canada welcomed 165,697 refugees, a substantive number which has continued to increase (Vineberg, 2018). Although in the $19^{\text {th }}$ and $20^{\text {th }}$ century the church was the center of community life in Canada, today every ethnic and public benefit group now has its own charitable/non-profit society focusing on services such as education, social, health and newcomer settlement programs (Hall et al., 2005).

\section{Late 1900's - Early 2000's The Rise and Fall of Third Sector \& State Relations}

The late 1900's marked the federal government's adoption of social welfare and security as a core responsibility. The official beginning date of the welfare state is highly debated; however, most academics agree that the modern foundations arose out of the experiences of the Great Depression and the Second World War, and were incrementally built upon from this time to the 1980s. "The welfare state aims to give citizens equal access to services, minimum income, and protection from economic hardships arising from old age, sickness, or unemployment” (Graham, 2001, p.8). In Canada, the welfare state is often referred to as the social safety net. As mentioned, prior to the mid-1900's there were no unemployment insurance or much in the way of social assistance in Canada, and those who needed service had to rely on private charities. The final push for the development of the welfare state came after the Great Depression. The roots of 
Canada's social welfare system were planted when a new political party, the Co-operative Commonwealth Federation (CCF), which emerged during the Great Depression, and promoted universal cooperation for the common good (Graham, 2001). As a socialist party the CCF wished to make governments responsible for social and economic planning and comprehensive social welfare (Graham, 2001). The CCF became the New Democratic Party in 1961. It never held national office but has governed at the provincial level in numerous places and times. However, at the federally level the social welfare ideas of the party have often been influential in shaping public policy.

Third Sector social service organizations came to rely heavily on government funding. However, as economic growth slowed in Canada, government revenues declined as well (Hall et al., 2005). During the 1990's, many Third Sector organizations experienced fiscal constraints as their funding declined (Elson, 2012). The funding structure that supported Third Sector organizations shifted to project based, contract funding. Ultimately, the form of their state funding and the levels of state funding changed while the need for the social services they provided continued. Prior to this time period, "many organizations had previously received grants that allowed them to operate according to their own principles, now they were often required to compete, sometimes with for-profit companies to deliver services according to strict government guidelines" (Hall et al., 2005, 22). Therefore, the relationship between the Third Sector and the State became complicated, as Third Sector organizations were working to meet the needs of civil society while also trying to address the administrative and restraint centered demands of state funders. 
In 1995 a group of twelve organizations created the Voluntary Sector Roundtable with the goal of improving the relationship between the Third Sector and the State. "Its primary goals were to enhance the relationship between the charitable sector and the federal government and to encourage a supportive legislative and regulatory framework for organizations in the community" (Voluntary Sector Initiative, 2006, par.1). The panel submitted a report in 1999 providing recommendations on how to improve the administrative relationship. Comparatively, the government adopted a Voluntary Task Force in 1999, which worked to create dialogue between the government and the Third Sector to discuss how to improve the administrative framework between each party (Elson, 2012). The result of this task force was a report titled, Working Together. Finally, in 2000, in response to both of these reports the federal government announced the development of the Voluntary Sector Initiative (VSI). The VSI was a five-year initiative that was worth $\$ 94.6$ million dollars to fund seven joint projects (Voluntary Sector Initiative, 2006). In the first phase of the project, the VSI worked on seven initiatives that focused on improving the relationship between the Third sector and the State. In phase one, the government and the Third Sector signed an Accord that represented the acknowledgment of partnership alongside of the adoption of two codes of good practice: A Code of Good Practice on Policy Dialogue and A Code of Good Practice on Funding (Voluntary Sector Initiative, 2006).

In phase two of the VSI, the Third Sector implemented the recommendations that resulted from phase one. Examples of these recommendations were reforms for registered charities, a Canadian volunteerism initiative and some funding for research on the sector (Elson, 2012). However, after these recommendations were implemented, the VSI disappeared because its funding was not renewed, monitoring of the implementation slowed and "responsibility for 
overall co-ordination [was] split between three government departments, making horizontal coordination difficult to achieve" (Elson, 2009, p. 56). The relationship between the Third Sector and the State became disorganized and one of exclusion.

Regarding immigration settlement and policy, the United Nations approved its Convention relating to the Status of Refugees in 1951. It defined a refugee as a person who:

"Owing to well-founded fear of being persecuted for reasons of race, religion, nationality, membership of a particular social group or political opinion, is outside the country of his nationality and is unable or, owing to such fear, is unwilling to avail himself of the protection of that country; or who, not having a nationality and being outside the country of his former habitual residence as a result of such events, is unable or, owing to such fear, is unwilling to return to it" (Vineberg, 2018, p.2).

In 1976, Canada passed a new Immigration Act. "Among its objectives, the Act was to fulfill Canada's international legal obligations with respect to refugees and to uphold its humanitarian tradition with respect to the displaced and the persecuted" (Canadian Council for Refugees, n.d.) Among other things, the Act enabled the private sponsorship of refugees influencing a new movement of settlement services. In 1978, The Canadian Council for Refugees was formed, under its original name, Standing Conference of Canadian Organizations Concerned for Refugees (Canadian Council for Refugees, n.d.) The Council is a national nonprofit committed to work towards the protection and rights of all refugees and vulnerable migrants around the world and to the settlement of immigrants and refugees in Canada. 


\section{Contemporary State -Third Sector Relationship}

\section{i. Neoliberalism}

The relationship between the Third Sector and the State has shifted significantly over time. In the post-WWII period of welfare state building in Canada, for example, an informal partnership between the State and Third Sector service providers developed. Both the public sector and the Third Sector grew together to meet expanding social and human service needs in society. The State provided finances to the sector in the form of block grants to carry out this work. The Third Sector became in effect largely under-recognized junior partners to the State during the welfare state construction. By the 1980s, however, there was shift in the policy paradigm away from Keynesian foundations to neoliberal principles, fundamentally changing the State's relationship with the Third Sector (Evans, Richmond \& Shields, 2005).

Neoliberalism can be understood as an "ideology that seeks to justify the restructuring of the economy to increase opportunities for private profit, often couched in such language as market freedoms and individual choice" (Stillwell, 2012, p. XVII). The adoption of neoliberal ideologies is marked by two periods: “until the 1970's, neoliberalism was used primarily to signify a category of economic ideas (classical laissez-faire liberalism) that arose in the 1830s1960s" (Venugopal, 2015, p.168). These economic ideas were grounded in the belief that competition is the defining feature of all relations. These ideas, however, were not dominant in the post-WWII period as Keynesian thought predominated. By the 1980s, however, Keynesian paradigm was superseded by the neoliberal paradigm, which marked the second period for neoliberalism where its ideas greatly influenced public policy. The history of the relationship 
between the Third Sector and the State also shifted in this period as neoliberal thinking came to rework the relationship. This is because, “by the early 1980's, neoliberalism was used in a very different way, as it came to describe the wave of market deregulation, privatization, and welfare state withdrawal that swept the first, second and third worlds" (Venugopal, 2015, p.168).

The wave of neoliberal ideals altered Third Sector organizations. Neoliberalism redefined "citizens as consumers whose democratic choices are best exercised by buying and selling, a process that rewards merit and punishes inefficiency" (COMER, 2016, p.2). The rise of consumerism pushed for social services to become privatized under a fundamental belief of a "natural" hierarchy: those at the bottom of the hierarchy deserve their lowly position because they have not taken take advantage of the economy (COMER, 2016). Neoliberalism's belief is that the market fairly rewards what individuals deserve. This ideology greatly resembles the separation of perspectives of deserving and undeserving citizens found in the Poor Law logic. In general, "governments influenced by neoliberal ideology have sought to cut back welfare state provisions, typically replacing citizen's universal entitlements to benefits with more selective targeting government expenditures" (Stillwell, 2012, p.208). Consistent with neoliberal theory, an effort to create a more equitable society is counterproductive. The withdrawal from the welfare state severely reduced the provision of all social services; and particularly affected immigrant and refugee settlement organizations.

\section{ii. The Neoliberal State}

As previously discussed, in order to understand the modern State, it is important to consider its liberal democratic, capitalist and bureaucratic aspects. Therefore, in order to 
understand the modern role of the Canadian State, it is critical to include in the analysis its neoliberal undertones.

In terms of democratic aspects, Canadian politics function within a framework of parliamentary democracy and a federal system of parliamentary government with strong liberal democratic traditions (Marland \& Wesley, 2017). The underlying principle of these terms is that in Canada, officials are elected to represent a group of people. As mentioned, a primary concern is that not all parts of the State are in fact democratic. An expanded political space has emerged due to the growth of institutions of national administration, therefore "judges, advocacy groups, citizens, the media and other political actors now coalesce outside the conventional venues of representative democracy (that is, legislatures and elections), challenging [Canadian] conceptualization of democratic discourse and decision making” (Marland \& Wesley, 2017, p. 383). Thus, the debate regarding democracy within the Canadian State remains one of the most contentious questions.

In the case of the modern neoliberal State, the private economic forces of neoliberalism challenge democratic processes. In the neoliberal Canadian State, "the pressure to redistribute resources, provide social welfare, ensure good governance, maintain democratic norms and uphold international human rights standards is found to be misplaced, premature and unfair" (Venugopal, 2015, p.178). The adoption of neoliberal social and economic policies leaves vulnerable populations with insufficient access to basic resources (Ypi, 2018). In the end, neoliberalism serves private interests who benefit from the economy and ignores class injustice as a democratic concern. 
The Canadian State was not antithetical to the development of a capitalist economy (Panitch, 2007). "In a dependent, staples-oriented economy such as Canada's, the state provided, partly out of economic necessity, partly out of close ties with the capitalist class, much of the technical infrastructure and economic regulation necessary to keep capitalism viable" (Panitch, 2007, par. 8). Theoretically, neoliberalism argues for the lean state, but in practice, continues to use the power and resources of the state to actively promote capitalism and private profit as well as to restructure citizens into consumers.

In terms of the bureaucratic processes, Canadian public administration is complex and contains a mix of multiple ideas, structures, methods and processes. Previous studies regarding Canadian public policy found that the underlying mechanism focused on partisan politics and ideology (Marland \& Wesley, 2017). This idea has continued to present day, however, "there has been a trend towards advocating for so-called evidence-based policy, necessitating increased empirical data and analytical competencies" (Marland \& Wesley, 2017, p.384). The adoption of evidence-based policy has sparked a concern that empirical data and analytical competencies can create tensions between institutions of national administration and political government. This tension strains professional duty to act on the wishes of political rulers in a non-partisan, responsible fashion (Marland \& Wesley, 2017). The tensions involved in the bureaucratic processes of Canadian public administration speak to the evolving role of the State in the lives of Canadian citizens as a whole and sparks a discussion over the very nature of governing itself. 
In the case of the modern neoliberal State, neoliberalism holds the belief that the defining feature of all relations is competition and self-interest (not public interest and public duty). This defining feature changes bureaucratic processes. Therefore, neoliberalism heightens the tensions between the institutions of national administration by enforcing accountability measures such as a high degree of reporting. An example of this tension is known as the "siloing" of institutions. "Siloing" is often adopted in a hierarchical (top down) organization structure originating in the early 1990's (Forsten-Astikainen et al, 2017). "Silos generate barriers and fragment organizations; organizational silos focus on fulfilling the function instead of achieving a process outcome" (Forsten-Astikainen et al, 2017, 475). Ultimately, silos are geared toward achieving their own objectives. In the State, silos limit horizontal communication among institutions of national administration. While the idea of siloing is quite common in institutions, diversity is needed for wider insight to develop strong policies (Ashforth et al., 2008). Within public administration, neoliberalism seeks to standardize the management of internal practices. In other words, bureaucratic practices become "silowed" and professionalized, enforcing accountability measures and a high degree of reporting.

Within the Canadian context the aspects of liberal democracy, capitalism and bureaucratic processes play a complex role in the composition of the State. Neoliberal undertones have significantly altered the modern State. "The ascendancy of neoliberal ideologies has undermined the perceived legitimacy of the substantial role of the state. Indeed, some see this as the primary political target of neoliberalism" (Stillwell, 2012, p. 208). Neoliberal practices have compromised the State by limiting it from delivering a policy framework that maintains a high standard of operations while protecting the public interest. 


\section{iii. Neoliberalism and the Third Sector}

It was previously identified, that the three essential roles of the public benefit service providing component of the Third Sector are representation, citizen engagement and service delivery. In order to understand the modern role of the Third Sector, it is important to consider these roles and the changes under neoliberalism. This section offers a broad description of the core concerns from within the Third Sector, before moving on to the specific issues impacting settlement organizations in Canada.

To begin, an essential role of Third Sector organizations is to act as representation and advocate for their target population. Organizations work to represent public concerns and opinions by actively building relationships within their community. In the neoliberal State organizations" "freedom to advocate on behalf of the community and their clients can be greatly constrained because of the fear of offending the government hand that funds them" (Moreno, 2016, p.74). As previously mentioned, the private economic forces of neoliberalism challenge democratic processes, as vulnerable populations and the concept of class injustice are not identified as a legitimate concern. As a result, many Third Sector organizations struggle to represent their community.

Critical to the role of the Third Sector is its ability to drive citizen engagement. Organizations are commonly viewed as a platform that provides communities with an opportunity to collectively discuss policy concerns and stay informed. In the neoliberal State, Third Sector organizations struggle to drive citizen engagement and face precarity, which is manifested in various ways: "in particular it is expressed in high levels of job insecurity 
experienced by those working in the sector both on the front line and those in managerial positions" (Baines et al, 2014, p.78). Short-term contracting is a result because a neoliberal state does not recognize the appropriateness of civil society to provide services, or as an entity to fund. The rise of consumerism pushed for the privatization of social services under the belief that there is a natural hierarchy where those who are on the lower end of the spectrum deserve their position. "Cut to the bone, non-profits find it increasingly challenging to maintain, let alone to strengthen, community connections" (Baines et al, 2014, 78). In the neoliberal state, Third Sector organizations struggle to drive citizen engagement because there is a lack of predictability and security within their own organization.

Lastly, key to the role of the public benefit service providing component of the Third Sector is its ability to provide an array of services that meet public needs. In the neoliberal state, two key issues hinder the provision of public services by Third Sector organizations; namely, the fiscal relationship and imposed accountability measures.

The fiscal relationship between the Third Sector and the State is characterized by project based, contract funding. Project based funding mechanisms promote short-term projects that are heavily regulated. As previously mentioned, neoliberalism holds the belief that the defining feature of all relations is competition and self-interest, which in turn affects bureaucratic processes. Therefore, the modern fiscal relationship between the Third Sector and the State "is built upon a competitive bidding process on service delivery contracts issued by the government [as] compelling competition among non-profit organizations is intended to marketize caring services and drive down costs in a bid to get the best value for the dollar" (Baines et al, 2014, 
p.79). This funding model promotes short-term services that undermine the ability of Third Sector organizations to develop sustainable services.

Within public administration, neoliberalism seeks to standardize the management of internal practices by "silowing" and professionalizing bureaucratic practices. Some have referred to this model as the non-profit starvation cycle, whereby funders and donors have unrealistic expectations for organizations while enforcing strict accountability measures such as a high degree of reporting, monitoring and short deadlines (Gregory \& Howard, 2009). Consequently, organizations must agree to funding that is tied to conditions decided by the funder, which in turn pressures organizations to conform to unrealistic expectations that they often do not have the capacity to meet (Gregory \& Howard, 2009). This professionalization causes organizations to stretch their mandate in order to receive funding and support. In the end, the Third Sector organizations face difficulties in maintaining its core mission and addressing the root causes of social issues.

Third Sector organizations are left at the will of the State as they depend on funding to be able to implement their programs. This model is simply "securing the poor through basic service delivery and institution building" (Dasouqi, 2016, p.12). Neoliberal ideologies have enforced a cycle that feeds short-term government funding and the standardization of practices, forcing once again a downloading of responsibility from the state to the individual and the Third Sector.

The contemporary relationship between the Third Sector and the State is one of mutual isolation. The neoliberal State has created a separation between the theory of best practice and 
the impact on the ground. The roles of representation, citizen engagement and the provision of services have been compromised by neoliberal practices, limiting organizations from meeting community needs. 


\section{Identifying Core Issues in the Provision of Settlement Services}

In Canada, immigration settlement policy is identified as efforts to regulate and facilitate the ways in which international migrants become integrated into society. As previously explained, the goal of settlement is for every immigrant to have the freedom to contribute to every dimension of Canadian society. Canada's governments have responded to the settlement and integration needs of newcomers by funding, mandating, and contracting out the delivery of settlement programs to Third Sector settlement agencies (Mukhtar, 2015). The relationship between the State and Third Sector settlement agencies was fundamentally altered with the adoption of neoliberalism in the1990s. Neoliberal ideologies became embedded in social welfare policies and subsequently in immigrant settlement funding policies (Mukhtar, 2015). Neoliberal restructuring of Third Sector organizations has limited the mandate of Third Sector settlement service providers.

Third Sector settlement service providers hold the same roles as those identified for the public benefit service-providing component of the Third Sector: representation, citizen engagement and the provision of services. Neoliberal influence on immigration settlement policy has generally resulted in the defunding of all but the service role (Moreno et al, 2016, p.77). The roles of representation and citizen engagement, when they take place, are now largely supported by the internal resources of settlement agencies.

Settlement service providers represent and advocate for Naturalized Citizens, Permanent Residents, Temporary Residents and Undocumented Migrants. Settlement agencies actively 
work to represent concerns and opinions by actively building relationships with the community and refugees within their region. With the adoption of neoliberal ideologies, Settlement Renewal restructured Third Sector settlement service providers' relationships with the State, "as they were stripped of their control over the development of settlement programming, methods of service delivery, and their ability to effectively advocate for newcomers" (Mukhtar, 2015, p.391). Settlement service providers became de-politicized because of their dependence on neoliberal government funding approaches, at the same time constraining their ability to advocate on behalf newcomers to Canada, lest they jeopardize their funding source.

As advocacy by Third Sector refugee settlement service providing organizations diminishes because of the workings of the contemporary neoliberal state, settlement agencies have experienced a number of negative consequences. The lack of advocacy and representation by Third Sector settlement organizations undermines the organization's legitimacy with its target newcomer group, preventing organizations from influencing governments regarding immigration policies and programs (Moreno et al, 2016). An additional consequence of diminishing advocacy is "a risk of underserving especially vulnerable groups, such as irregular migrants, since the eligibility criteria imposed by public funding requirements oftentimes forbids [organizations] from serving those newcomers in government funded programs who are most in need, in particular migrants with less than full legal status" (Moreno et al, 2016, 76). Third Sector settlement organizations are better positioned as community, ground level organizations to serve newcomers to Canada. Organizations are better positioned because of their "special knowledge in working with local communities to provide services that can be more attuned to the special needs of clients, including racial and ethnic minority migrants” (Moreno et al, 2016, p.75). 
Settlement organizations have the ability to build community connection, meaning groups, such as irregular migrants, are more likely to make use of their services.

Settlement organizations face limitations due to their dependence on government funding, which directly curtails their capacity to advocate for social justice. Neoliberal influence on immigration settlement policy has left Third Sector settlement service providers without an effective voice, unable to fulfill their mandates.

A second critical role of Third Sector settlement organizations is their ability to drive citizen engagement. Settlement organizations often work to drive community engagement, sometimes through the sponsorship of refugees and migrants. In the neoliberal state, Third Sector settlement organizations struggle to drive citizen engagement. Short term funding, and government dependence on funding creates constant turnover, which "undermines the ability of organizations to develop the human and intellectual capital they require, at the same time, fewer resources are available to support activities, such as the management and development of the organization's paid staff and volunteers" (Hall, 2005, p.26). This lack of security puts strain on Third Sector workers and volunteers.

As previously mentioned, short-term contracting is a result of neoliberalism. The neoliberal, consumerist State does not recognize social services to be essential. There is a natural hierarchy where those who are in need of social services are blamed for their lack of initiative. Citizen engagement has been capitalized, distancing organizations from newcomers. "Accordingly, [organizations] may be conceptualized as the distributors of settlement services 
that serve the need of the supplier of settlement funding (government) rather than the consumers of their services (newcomers)" (Mukhtar, 2015, p.392). This reinforces neoliberal ideologies, distancing organizations from the newcomers they are trying to serve. "Following on this idea, if newcomers are unable to adapt, it is thought to be their responsibility, which invisibilizes the fact that there may be a lack of sufficient settlement support" (Moreno et al, 2016, p.79). Ultimately, the onus for integration shifts to newcomers, individuals and families aided by underfunded Third Sector settlement agencies.

As fewer resources become available to support activities, settlement organizations are unable to effectively engage with communities. Organizations struggle to provide a platform to give communities an opportunity to collectively discuss and stay informed on immigration settlement in their region. "Problems arise when there is a lack of transferred resources from the central state to provide regional and local jurisdictions with enough funding to match expected settlement resource levels" (Moreno et al, 2016, p.76). This in turn, leaves regions under resourced struggling to serve newcomer populations. In the neoliberal state, Third Sector settlement organizations struggle to drive citizen engagement because there is a lack of predictability and security within their own organization.

Without a focused drive towards citizen engagement by settlement organizations, public and community attitudes towards immigration have turned. "Austerity has made government resources to support settlement generally harder to secure, anti-immigration forces have gained influence at the political level and public attitudes towards newcomers are more negative" (Moreno et al, 2016, p.78). It is important to recognize that State support for immigration 
settlement policy sends a message to the greater society. Without government support, organizations are not only experiencing a lack of predictability from within their organization, they are also experiencing a lack of security from the community. "Aside from attempting to provide direct services to newcomers, [organizations], where resources permit, are also often engaged in various community-based educational activities aimed at promoting the benefits of immigration and in challenging populist xenophobic attitudes" (Moreno et al, 2016, p.78).

Neoliberal influence on immigration settlement policy has left Third Sector settlement organizations struggling to sustain their own organization, while also struggling to maintain community support for newcomers to Canada.

Key to the role of the Third Sector settlement organizations is their ability to provide services that meet newcomer needs. Organizations, "serve as mediators between the government and the individual migrant, as they comply with the state's settlement responsibilities towards newcomers while enforcing migrant's rights" (Moreno et al, 2016, p.80). In the neoliberal state, two central issues prevent the provision of public services by Third Sector organizations: the fiscal relationship and imposed accountability measures. These issues significantly undermine the work of settlement organizations, and prevent them from supporting sustainable services to newcomers to Canada.

The fiscal relationship between Third Sector settlement organizations and the State is characterized by project based, contract funding, influencing short-term projects that are heavily regulated. Settlement Renewal aimed to transfer the State's responsibility for the provision of 
social services to ground level while simultaneously cutting funding for immigrant services overall. "The Settlement Renewal Policy replaced core funding with competitive purchase-ofservice contract funding to finance federally defined settlement programs" (Mukhtar, 2015, p.391). Settlement programming is now defined as competitively sourced and short-term. Federal settlement programs aim to marketize social services resulting in newcomers to be viewed as an economic item. "In this context, it is not uncommon for settlement services to be viewed as an investment that is not quite paying off, hence the retrenchment of public money for these kinds of programs can be justified (Moreno et al, 2016, p.79). The funding that does get contracted strictly focused on the first stages of settlement that concern immediate survival needs (Evans, Richmond \& Shields, 2005). This leaves newcomers with little agency to contribute to society and downplays the need of receiving communities to change in order to better accommodate newcomers (Moreno, 2016), thereby limiting integration into society.

In addition to a focus on short term funding, Settlement Renewal by neoliberal ideologies imposed funding requirements that continue to limit settlement service providers. "Requirements for immigrant selection have shifted heavily towards migrants with high human capital who are deemed better able to provide for themselves and their families thus purportedly reducing their need for publicly funded settlement services" (Jupp, 2011, p.41). As indicated, neoliberalism holds the belief that the defining feature of all relations is competition and self-interest. Therefore, in the context of settlement organizations, newcomers are seen as a possible economic investment, and are assessed based on what human capital and skills they can bring to Canadian society. "Neoliberalism recognizes the economic value of immigration and engages the global competition for migrant talent to fill labour and migrant gaps" (Root et al, 2014, p.16). In 
addition, funding priorities are predetermined by the State, and are enforced in the terms and conditions of the funding agreement. For example, a settlement program may "prioritize direct service provision by allocating $90 \%$ of its funds for direct services, leaving only $10 \%$ for the indirect services associated with horizontal governance and capacity building" (Neudorf, 2016, p.95). Consequently, Third Sector settlement organizations may align their interests with that of the State even though they may not match with the identified needs of newcomers.

The administrative relationship between Third Sector settlement organizations and the State is characterized by imposed accountability measures. Neoliberalism seeks to standardize the management of internal practices by enforcing bureaucratic practices that professionalize organizations. The accountability measures imposed restrict settlement organizations from delivering services. "Concurrently, immigration settlement agencies are subjected to increased evaluation standards, accountability requirements, administrative responsibilities, and government monitoring and oversight" (Mukhtar, 2015, p.392). Settlement organizations continue to run through the non-profit starvation cycle, being forced to conform to unrealistic expectations that they do not have the capacity to meet. Neoliberalism envisioned "an accountability regime that combined the measurement of outputs, outcomes, and financial resources to ensure that the activities of organizations were achieving results efficiently" (Neudorf, 2016, p.94). However, instead accountability measures under neoliberal governance has and continues to been used to regulate Third Sector settlement organizations to bring them in line with State objectives, making it difficult for providers to maintain a core mission and address the long term needs of newcomers. 
Neoliberal restructuring of Third Sector settlement organizations has limited service providers from supporting newcomers in Canada. Neoliberal ideologies have enforced a cycle that feeds short-term government funding and the standardization of practices, driving a downloading of responsibility from the State to the individual newcomer and family. The State is then able to control the work of settlement organizations from a distance through funding agreements and accountability measures (Shields and Evans, 1998). This enables the State to avoid accountability for the delivery of services and transfers any pre-determined social obligations to civil society. 


\section{Restructuring Relations}

Canada is home to one of the largest Third Sectors in the world. However, Canadian governments have failed to give the Third Sector the attention it warrants in public administration and public policy. Canada is also home to one of the largest immigration and refugee populations, welcoming more than 286,000 permanent residents in 2017 -- keeping in mind that this number only represents one status of migrant. However, Canadian governments continue to enforce neoliberal informed approaches that not only greatly circumvent service delivery, but also prevent change in the relationship between the Third Sector and the State.

Critical to the understanding of settlement services is that they are a continuous process between numerous stakeholders. "The settlement process involves not just immigrants and service providers, but policy makers, media, employers, labor organizations, learning institutions, faith communities, neighbors and the broader community" (OCASI \& COSTI, 1999, p.13). A restructured relationship between Third Sector settlement organizations and the State that focuses on collaboration has the ability to improve the provision of services to newcomers in Canada while benefitting everyone involved. Third Sector settlement organizations do have a significant role in the settlement of newcomers. However, it is focused almost exclusively on government directed forms of service delivery and not wider participation in decisions or the development of procedures, referred as co-production. " $[\mathrm{C}] \mathrm{o}-$ production is concerned primarily with involvement of Third Sector actors in the delivery or implementation of public policy" (Evans \& Sapeha, 2015, 3), whereas "the term co-construction is concerned with public policy 
when it is being designed and not merely to when it is being implemented" (Evans \& Sapeha, 2015, p.3).

As mentioned, the IRCC is Canada's federal governing body that oversees Immigration, Refugees and Settlement procedures. Through grants and contributions agreements the IRCC funds Third Sector service providers to provide settlement under six main categories including: "Needs Assessments and Referrals, Information and Orientation, Language Assessments, Language Training, Employment-Related Services and Community Connections" (Immigration Refugees and Citizenship Canada, 2017, p.1). The IRCC also focuses on six settlement support services, including: "Care for Newcomer Children, Transportation, Translation, Interpretation, Disability Support and Crisis Counseling" (Immigration Refugees and Citizenship Canada, 2017, p.1). In addition to providing funding to Third Sector settlement service providers, the IRCC attempts to engage provinces and territories to deliver settlement services to newcomers. As argued, these procedures are strongly shaped by neoliberalism that enforces professionalization, strict control systems and 'value for money' thinking that often prevent settlement organizations from fully meeting the needs of newcomers in Canada.

Adopting mechanisms that prioritize collaborative governance is the first step towards co-production. Kirk Emerson, Tina Nabatchi and Stephen Balogh (2012) define collaborative governance broadly, "as the processes and structures of public policy decision making and management that engage people constructively across the boundaries of public agencies, levels of government, and/or the public, private and civic spheres in order to carry out a public purpose that could not otherwise be accomplished" (p.2). Adopting a broad definition of collaborative 
governance allows for distinctions among different communities. Governance works to regulate and influence actions, and can apply to any sector including the private, public and civic sector (including the Third Sector). Key to collaborative governance is that this governance occurs across boundaries, engaging all sectors together. The interest in collaborative governance has grown over the past couple of years. Within the literature on collaborative governance, the approach to public administration and public policy is argued to be a strong orientation towards complex policy issues that involve multiple stakeholders. "The attention to collaboration flows from policy analyses demonstrating that today's most urgent national priorities, from sustainable development to poverty reduction and economic innovation, are wicked in their complexity and localized in their expression" (Bradford, 2016, p.660).

By adopting collaborative governance approach, the Federal government of Canada can begin to counteract the characteristics of neoliberalism that have been entrenched in its relationship with Third Sector settlement organizations. Collaborative governance will help stakeholders to develop a mutual understanding of one another's roles and responsibilities. Collaborative governance will additionally enable all participating stakeholders in developing mutually beneficial funding agreements, as well as discuss accountability arrangements that will better serve all involved stakeholders and newcomers.

As a whole, collaborative governance will push all involved stakeholders to develop a mutual understanding of one another's roles and responsibilities. Through Collaborative Governance, institutions of national administration can engage with Third Sector settlement organizations and build relations on the principle that settlement is important to Canada. Although the Third Sector 
and the State may have different motivations for settlement, they can both agree that settlement is important to Canada as a country. This overall adoption of Collaborative Governance will counteract the hierarchical traditions of neoliberalism and push for the recognition of Third Sector roles.

Collaborative Governance builds capacity for joint action. This action is set to take place on an equal playing field as "ccollaborative arrangements take hold through trial-and-error learning that alters calculations of self-interest to generate community rules" (Bradford, 2016, p.663). The joint action of all stakeholders will help to counter neoliberal hierarchal beliefs that "the purpose of collaboration is to generate desired outcomes together that could not be accomplished separately (Emerson, Nabatchi \& Balogh, 2012, p.14). Joint action will build capacity in all stakeholders, as improving settlement processes will not be possible without the voice of all involved parties. As previously mentioned, neoliberal influence on Immigration Settlement Policy has left Third Sector settlement service providers without an effective voice. By collaborating with the State, Third Sector Settlement organizations will be able to advocate for newcomers without feeling pressure to conform to the State.

In addition, trust has been recognized as a key priority in Collaborative Governance, “because it can ensure adherence to agreed rules; promote understanding of others' interests, needs, and values (Ran \& Qi, 2019, p.613). This statement recognizes that through Collaborative Governance the State can come to understand the role of Third Sector settlement organizations and vice versa. By collaborating with the State, Third Sector settlement organizations will be able to fulfill their mandate by successfully representing newcomers and voicing localized 
concerns directly to the State. Collaborative Governance is achievable through active engagement as all stakeholders can discuss localized issues and best practices towards improving Immigration Settlement Policy.

Key to Collaborative Governance is its ability to drive agreements to a set of rules and procedures, thereby enabling stakeholders to discuss funding arrangements and best practices. As previously stated, two central issues under a neoliberal State that prevent the provision of public services by Third Sector settlement organizations: the fiscal relationship and imposed accountability measures. Currently, settlement funding is defined as competitively sourced and short-term. Collaborative Governance creates a shared administration between stakeholders and gives rise to horizontal network management and collaborative public management (Emerson, Nabatchi \& Balogh, 2012). This means that administration and funding will be based on and agreed to an adhered set of rules established horizontally across stakeholders instead of through a competitive process. "Collaborative governance differs from traditional command and control arrangements in its use of negotiation, dialogue, deliberation, and consensus" (Amsler, 2016, p.702). By engaging in negotiation, dialogue and consensus through Collaborative Governance, the Third Sector and the State can collaborate to build programming that supports newcomers through the entire settlement process while giving them the tools to be able to contribute to Canada's society. An accountability framework that focuses on a mutually agreed upon responsibilities and expectations by both the Third Sector and the State offers a possibility for a new approach to public sector management. 
Overall Collaborative Governance can be utilized to restructure the relations between the Third Sector and the State. A shared understanding will help build relations and provide a platform to share concerns from both sides of the sector, such as concerns around reporting and precarity. Collaborative Governance can help to facilitate access to settlement programming as well as in identifying additional services that support the development of partnerships, capacitybuilding and the sharing of best practices among Third Sector settlement service providers across Canada. 


\section{Recommendations Related to Settlement Services}

Based on the assessment of the current relationship between Third Sector settlement organizations and the State, it is recommended that the federal Government of Canada adopt collaborative governance approaches in settlement services to better serve newcomers to Canada.

Specifically, it is recommended that the IRCC propose a Call for Proposals (CFP) for designated Third Sector settlement organizations to lead the development of an Advisory Committee to begin the groundwork for such a collaborative governance approach.

It is recommended that Settlement Advisory Committees be established in each community seating an equal amount of stakeholders encompassing the private, public and Third Sector.

$>$ The adoption of a broad definition of collaborative governance will allow for the development of community specific plans that serve each unique community's newcomer population. This will allow for the establishment of mutually agreed upon roles, responsibilities and expectations.

The State should continue to directly fund settlement service providers while engaging with provinces and territories to deliver settlement services to newcomers, however, now through a collaborative lens. 


\section{Conclusion}

The current relationship between Third Sector settlement organizations and the State demonstrates a restrictive bond shaped by neoliberal practices. Because the framework for managing the relations between the Third Sector and the State is unclear, there is a lack of coherence among stakeholders in the migrant settlement process often preventing newcomers from full integration into Canadian society.

This MRP is a call for action to Third Sector settlement organizations and the State to reconcile and strengthen their relationship. The Third Sector plays a critical role in developing programs and providing services that meet newcomer needs at the local level where settlement actually takes place.

Today, there continues to be a declining capacity of Third Sector organizations to meet their roles and provide adequate services to newcomers. In Canada, settlement organizations have a long history of providing services that support newcomers in settling to their new community. Entrenched neoliberal ideologies however have weakened Third Sector organizations resulting in a downloading of responsibilities from the State to the individual newcomers, their families or to non-profit service providers.

In the past the disciplines of Public Policy and Public Administration have overlooked the role of the Third Sector in relation to the management of policies and programs. However, through co-construction, the relationship between settlement organizations and the State can be transformed into a collective approach. Collaborative governance will lay emphasis on a shared 
understanding and facilitate the development of partnerships, capacity building and the sharing of best practices among settlement service providers.

The contemporary relationship between the Third Sector and the State reflects a downloading of responsibility from the State to the individual and the Third Sector. In reality, the responsibility of settlement rests on the shoulders of all Canadians. Involving not just immigrants and service providers, but governments, sponsorship organizations, faith groups, cities, neighborhoods and the broader community. In order support newcomers to participate fully in Canadian society for their benefit and the larger benefit of Canadian society, the Third Sector and the State must establish a new restructured relationship from the bottom up. 


\section{References}

Amsler, L.B. (2016). Collaborative governance: Integrating management, politics, and law. Public Administration Review, 76(5), 700-711.

Ashforth, B.E., Harrison, S.H., \& Corley, K.G. (2008), Identification in organizations: an examination of four fundamental questions. Journal of Management, 34(3), 325-374.

Baines, D., Campey, J., Cunningham, I. \& Shields, J. (2014). Not profiting from precarity: the work of non-profit service delivery and the creation of precariousness. Just Labour: A Canadian Journal of Work and Society (22), 74-93.

Bradford, N. (2016). Ideas and collaborative governance: a discursive localism approach. Urban Affairs Review, 52(5), 659-684.

Brandsen, T., \& Pestoff, V. (2006). Co-production, the third sector and the delivery of public services. Public Management Review, 8(4), 493-501.

Britannica, T. E. (2009, August 21). State. Retrieved from https://www.britannica.com/topic/state-sovereign-political-entity

Bushell, R., \& Shields, J. (2018). Immigrant Settlement Agencies in Canada: A Critical Review of the Literature through the Lens of Resilience. Social Sciences and Humanities Research Council of Canada. Retrieved from https://www.academia.edu/37595008/Immigrant_Settlement_Agencies_in_Canada_A_Cr itical_Review_of_the_Literature_through_the_Lens_of_Resilience

Canada Revenue Agency. (2016, June 23). What Is the Difference between a Registered Charity and a Non-Profit Organization? Retrieved from 
www.canada.ca/en/revenue agency/services/charities-giving/giving-charity-informationdonors/about-registered charities/what-difference-between-a-registered-charity-a-nonprofit-organization.html.

Canadian Council for Refugees. (n.d.) Brief history of Canada's responses to refugees. Retrieved from https://ccrweb.ca/sites/ccrweb.ca/files/static-files/canadarefugeeshistory.htm

Canadian Museum of Immigration. (n.d.) Immigration Act, 1869. Retrieved from https://pier21.ca/research/immigration-history/immigration-act-1869

Citizenship Canada. (2019, February 26). 2018 Annual Report to Parliament on Immigration. Retrieved from https://www.canada.ca/en/immigration-refugees-citizenship/corporate/publicationsmanuals/annual-report-parliament-immigration-2018/report.html

Dasouqi, A. (2016). Refugee industrial complex, neoliberal governance within the resettlement industry and its effects: Is an alternative structure possible? International Development, Community and Environment (IDCE), 1-69.

Derrick, T. (2011). Personnel networks and the economic adjustment of immigrants. Statistics Canada: Component of Statistics Canada dialogue, 52-61.

Elson, P. (2009). A short history of voluntary-sector-government relations in Canada. The Philanthropist, 21(1), 36-74.

Elson, P. (2012). Canada's voluntary sector initiative and sub-national voluntary sectorgovernment relations: A third wave. Nonprofit Policy Forum, 3(2), 1-31.

Emerson, K., Nabatchi, T., \& Balogh, S. (2012). An integrative framework for collaborative governance. Journal of Public Administration Research and Theory: J-PART, 22(1), 129. 
Evans, B., Richmond, T., \& Shields, J. (2005). Structuring neoliberal governance: The nonprofit sector, emerging new modes of control and the marketization of service delivery. Policy and Society, 24(1), 73-97.

Evans, B., \& Sapeha, H. (2015). Are non-government policy actors being heard? Assessing new public governance in three Canadian provinces: POLICY ENGAGEMENT. Canadian Public Administration, 58(2), 249-270.

Forsten-Astikainen, R., Hurmelinna-Laukkanen, P., Lämsä, T., Heilmann, P., \& Hyrkäs, E. (2017). Dealing with organizational silos with communities of practice and human resource management. Journal of Workplace Learning, 29(6), 473-489.

Global Policy Forum. (n.d.). What is a "State"? Retrieved from https://www.globalpolicy.org/nations-a-states/what-is-a-state.html

Graham, J. R., \& Querido, L. M. (2001). Canadian social welfare in the twenty-first century. Journal of Canadian Studies, 35(4), 297-304.

Gregory, A., \& Howard, D. (2009). The nonprofit starvation cycle. Stanford Social Innovation Review, 47-53.

Hall, M., Barr, C., Easwaramoorthy, M., Sokolowski, S., \& Salamon, L. (2005). The Canadian Nonprofit and Voluntary Sector in Comparative perspective. Johns Hopkins Comparative Nonprofit Sector Project, \& Imagine Canada.

Immigration, Refugees and Citizenship Canada. (2017). Evaluation of the settlement program: Research and evaluation. Retrieved from https://www.canada.ca/content/dam/ircc/documents/pdf/english/evaluation/e2-2016settlement-en.pdf 
Jupp, J. (2011). Politics, public policy and multiculturalism. Multiculturalism and integration: A harmonious relationship (pp. 41-53). Canberra: ANU Press.

Kapucu, N. (2014). Complexity, governance, and networks: Perspectives from public administration. Complexity, Innovation and Policy, 1(1), 29-38

Karkkainen, B. (2004). New governance in legal thought and the world. Minnesota Law Review, 471-99.

Laforest, R. (2011). Voluntary sector organizations and the state: Building new relations. Vancouver: UBC Press.

Lautenschlager, J. (1992). Volunteering: A traditional Canadian value. Ottawa: Voluntary Action Program: Canadian Heritage.

Marland, A., \& Wesley, J. J. (2017). Surveying the Canadian state: Evolution of Canadian political science, politics, and government since 1967. Canadian Journal of Political Science, 50(1), 377-393.

Mayrl, D., \& Quinn, S. (2016). Defining the state from within. Sociological Theory, 34(1), 1-26.

Maurutto, P. (2005). Charity and public welfare in history: A look at Ontario, 1830-1950. The Philanthropist, 19(3), 159-167

McRoberts, K. (2001). Canada and the multinational state. Canadian Journal of Political Science/Revue Canadienne De Science Politique, 34(4), 683-713.

Mukhtar, M., Dean, J., Wilson, K., Ghassemi, E., \& Wilson, D. (2015). The challenges immigrant settlement agencies (ISAs) encounter in a suburban setting in Ontario, Canada. Migration \& Integration, 390-408. 
Neudorf, E. G. (2016). Key informant perspectives on the government of Canada's modernized approach to immigrant settlement. Canadian Ethnic Studies, 48(3), 91-107.

Panitch, L. (2007, February 7). State. Retrieved from https://www.thecanadianencyclopedia.ca/en/article/state

Phillips, S., \& Smith, S. (2011). In Governance and Regulation in the Third Sector. New York and London: Routledge.

Pierson, C. (2012). Modern State. Florence: Taylor and Francis.

Praznik, J. \& Shields, J. (2018). Government of Ontario's role in immigration and settlement. Social Sciences and Humanities Research Council of Canada. Retrieved from https://bmrc-irmu.info.yorku.ca/files/2018/10/Resilience-Government-of-Ontarios-Rolein-Immigration-and-Settlement-Jessica-and-John-October-1-2018.pdf

Qvist, M. (2017). Meta-governance and network formation in collaborative spaces of uncertainty: The case of Swedish refugee integration policy. Public Administration Review, 95(2), 498-511.

Ran, B., \& Qi, H. (2019). The entangled twins: Power and trust in collaborative governance. Administration \& Society, 51(4), 607-636.

Reed, P., \& Howe, V. (1999). Defining and Classifying the Nonprofit Sector. Statistics Canada. 1-65.

Root, J., Gasse, E., Shields, J., \& Bauder, H. (2014). Discounting immigrant families: Neoliberalism and the framing of Canadian immigration policy change. Ryerson Centre for Immigration and Settlement. Retrieved from https://www.ryerson.ca/content/dam/rcis/RCIS-WP-Root-No2014-7.pdf 
Schmidt, R. (2007). Comparing federal government immigrant settlement policies in Canada and the United States. American Review of Canadian Studies, 37(1), 103-122.

Shields, J., Drolet, J. \& Valenzuela, K. (2016). Immigrant settlement and integration services and the role of nonprofit providers: A cross-national perspective on trends, issues and evidence. Ryerson Centre for Immigration and Settlement. Retrieved from https://www.ryerson.ca/content/dam/rcis/documents/RCIS\%20WP\%202016_01\%20Shiel ds $\% 20$ et $\% 20$ al $\% 20$ final.pdf

Shields, J. \& Evans, B. 1998. Shrinking the State: Globalization and the "Reform" of Public Administration. Halifax: Fernwood.

Stilwell, F. (2012). Political economy: The contest of economic ideas, 3rd Edition. Victoria, Australia: Oxford University Press.

Wachhaus, A. (2014). Governance beyond government. Administration and Society, 46(5), 573593.

Waite, P. B. (2013, September 22). Confederation. Retrieved from https://www.thecanadianencyclopedia.ca/en/article/confederation

Watson, R. (1985). Charity and the Canadian income tax: An erratic history. The Philanthropist, $5(1), 3-21$.

Venugopal, Rajesh., (2015). Neoliberalism as a concept. Economy and Society 44(2), 165-187. Vineberg, R., (2018). Canada's refugee strategy - how it can be improved. The School of Public Policy Publications, 11(14), 1-18.

Voluntary Sector Initiative. (2006). Goals of the Voluntary Sector Initiative. Retrieved from http://www.vsi-isbc.org/eng/about/goals.cfm 
Ypi, K., (2018). Borders of class: Migration and citizenship in the capitalist state. Ethics and International Affairs. 32(2), 141-152. 